\title{
ZRANB3 wt Allele
}

National Cancer Institute

\section{Source}

National Cancer Institute. ZRANB3 wt Allele. NCI Thesaurus. Code C116086.

Human ZRANB3 wild-type allele is located in the vicinity of $2 q 21.3$ and is approximately $394 \mathrm{~kb}$ in length. This allele, which encodes DNA annealing helicase and endonuclease ZRANB3 protein, plays a role in both DNA rewinding and the response to DNA damage. 